\title{
(6) OPEN ACCESS \\ Transparency as a remedy against racketeering: preventing and restraining fraud by exposing Big Tobacco's dirty secrets
}

\author{
Monique E Muggli, ${ }^{1}$ Howard M Crystal, ${ }^{2}$ Kim Klausner $^{3}$
}

${ }^{1}$ Campaign for Tobacco-Free Kids, International Legal Consortium, Washington DC, USA

${ }^{2}$ Meyer Glitzenstein \& Crystal, Washington DC, USA

${ }^{3}$ University of California, San Francisco, California, USA

\section{Correspondence to}

Monique E Muggli, Campaign for Tobacco-Free Kids, International Legal Consortium; 1400 I (Eye) Street NW, Suite 1200 Washington, DC 20005, USA; mmuggli@tobaccofreekids.org

Received 24 April 2014 Accepted 1 July 2014 Published Online First 22 July 2014

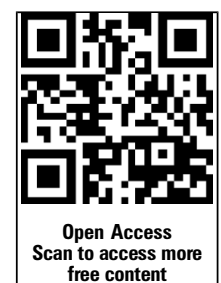

CrossMark

To cite: Muggli ME, Crystal HM, Klausner K. Tob Control 2015;24:514-518.

\section{ABSTRACT}

The 1990s state litigation that resulted in the tobacco industry's initial document disclosure obligations fully expired in 2010. These obligations have been extended and enhanced until 2021 through a federal lawsuit against the tobacco industry over violations of the Racketeer Influenced Corrupt Organizations Act (RICO). In this special communication, we summarise and explain the new legal framework and enhanced document disclosure obligations of the major US tobacco companies. We describe the events leading up to these new requirements, including the tobacco companies' failed attempt to close the Minnesota Tobacco Document Depository, the release of 100000 documents onto the companies' document websites discovered to have been publicly available at the Minnesota Tobacco Document Depository but not online, and the addition of over 2300 documents to those websites, which are also now publicly available at Minnesota after being secured for years in a separate, non-public storage room at the Minnesota Tobacco Document Depository. We also detail the document indexing enhancements and redesign of the University of California, San Francisco's Legacy Tobacco Documents Library website, made possible by the RICO litigation, and which is anticipated to be released in September 2014. Last, we highlight the public health community's continued opportunity to expose the US tobacco industry's efforts to undermine public health through these new search enhancements and improved document accessibility and due to the continuously growing document collection until at least 2021.

\section{INTRODUCTION}

One of the most important legacies of the decadeslong litigation against the major US and UK tobacco companies is the millions of pages of internal corporate records primarily available at the Minnesota Tobacco Document Depository (Minnesota Depository) and at British American Tobacco's (BAT) document archive in England (Guildford Depository) as well as on the internet (table 1). Findings, commentary and research methodologies about these materials have been well documented. ${ }^{1}$

The 1990s state litigation that resulted in settlements in Minnesota ${ }^{2}$ and nationally via the Master Settlement Agreement (MSA) ${ }^{3}$ led to the tobacco companies' initial document disclosure obligations which began in 1998 and expired in 2008 and 2010, respectively. ${ }^{4}$ However, these obligations have now been extended and enhanced with additional transparency measures until 1 September 2021 through a federal lawsuit, filed by the USA in
1999, over the tobacco companies' civil violations of the Racketeer Influenced Corrupt Organizations Act (RICO). We summarise and describe the RICO defendants' new and enhanced document disclosure obligations and the events in the litigation leading up to these new requirements.

\section{METHODS}

Public filings and judicial orders or opinions from the USA District Court for the District of Columbia were reviewed. University of California, San FranciscoLegacy Tobacco Documents Library's (LTDL) Tobacco Documents Bibliography ${ }^{1}$ was consulted for recent tobacco document research scholarship.

\section{RESULTS}

US racketeering-based litigation against the tobacco industry

In 1999, the USA sued the major US-based and UK-based cigarette manufacturers for deliberately deceiving the American public about the risks and dangers of cigarette smoking, including exposure to tobacco smoke, in violation of RICO. ${ }^{5}$ After many years of litigation, in 2006, the Honourable Gladys Kessler of the US District Court for the District of Columbia released her ground-breaking decision, finding that the cigarette companies had engaged in a decades-long conspiracy, in violation of RICO, to defraud the public about: (1) the adverse health effects of smoking and exposure to secondhand tobacco smoke; (2) the addictiveness of nicotine and their manipulation of nicotine levels and (3) the health benefits of their 'low tar' brands. Judge Kessler further found that the major tobacco companies were likely to continue their unlawful behaviour, and crafted equitable relief designed to 'prevent and restrain' those future violations, as authorised under RICO. ${ }^{6}$ These remedies ${ }^{7}$ include a requirement to continue to publicly disclose (nonprivileged and non-confidential) internal documents produced in US-based smoking and health litigation for 15 years until 1 September $2021 .{ }^{6}{ }^{8}$ In a 2011 ruling, the Court held that BAT was not subject to the Court's jurisdiction under the RICO Act, so the Court's Final Order does not cover BAT. ${ }^{9}$

\section{Implementation of the racketeering case Final Order}

The Defendants sought to stop implementation of Judge Kessler's Final Order through the appeals process-including failed efforts to obtain a hearing before the US Supreme Court-that lasted almost 4 years. Ultimately, almost all of Judge Kessler's liability findings and remedies were 
Table 1 Current information for accessing the tobacco company documents

\begin{tabular}{|c|c|}
\hline $\begin{array}{l}\text { Minnesota Tobacco Document } \\
\text { Depository }\end{array}$ & $\begin{array}{l}\text { Phone: (612) } 378-5707 \\
\text { Address: } 1045 \text { Westgate Drive, Suite } 40 \text {, } \\
\text { Minneapolis, MN 55114, USA }\end{array}$ \\
\hline $\begin{array}{l}\text { British American Tobacco } \\
\text { document depository }\end{array}$ & $\begin{array}{l}\text { Phone: (44) 148-346-4300 } \\
\text { Address: Unit 3A, Opus Business Park, } \\
\text { Moorfield Road, Slyfield, Guildford GU1 } \\
\text { 1SZ, UK }\end{array}$ \\
\hline $\begin{array}{l}\text { University of California, } \\
\text { San Francisco-Legacy Tobacco } \\
\text { Documents Library }\end{array}$ & http://legacy.library.ucsf.edu \\
\hline \multicolumn{2}{|c|}{ Court-ordered tobacco company document websites } \\
\hline Philip Morris USA, Inc & http://www.pmdocs.com/ \\
\hline $\begin{array}{l}\text { R.J. Reynolds Tobacco Company, } \\
\text { American Tobacco and Brown \& } \\
\text { Williamson }\end{array}$ & $\begin{array}{l}\text { http://www.rirtdocs.com/rjrtdocs//index. } \\
\text { wmt?tab=home }\end{array}$ \\
\hline Lorillard Tobacco Company & $\begin{array}{l}\text { http://www.lorillarddocs.com/public/index. } \\
\text { wmt?tab=home }\end{array}$ \\
\hline $\begin{array}{l}\text { The Council for Tobacco Research } \\
\text { USA, Inc }\end{array}$ & $\begin{array}{l}\text { http://www.ctr-usa.org/ctr/index.wmt? } \\
\text { tab=home\&tab=home }\end{array}$ \\
\hline The Tobacco Institute & http://www.tobaccoinstitute.com/ \\
\hline
\end{tabular}

upheld, including all the document disclosure obligations. ${ }^{10}$

The Defendants' document disclosure obligations under the MSA and the Minnesota Settlement were set to expire during that appeal period, and because the Final Order was not being implemented during the appeal, the Defendants would have been free to stop complying. To avoid that outcome, the USA and Public Health Intervenors (Intervenors; table 2) obtained Defendants' commitment to continue these disclosures pending resolution of the appeals. ${ }^{11}$

There was only one issue that Judge Kessler ruled should be further considered under her Final Order: coding or indexing obligations for material uploaded to the Defendants' document websites. As discussed below, the subsequent mediation on this issue led to several additional disclosure-related obligations.

\section{Minnesota Depository}

Defendants' failed attempt to close the Minnesota Depository results in the online release of 100000 documents

Judge Kessler asserted jurisdiction over the Minnesota Depository, which had been under the jurisdiction of a Minnesota court, on 15 September 2011. ${ }^{12}$ In March 2011, the Defendants sought to close the Minnesota Depository. ${ }^{13}$ The Defendants argued that they would upgrade their company document websites to make available non-standard media in digitised format, thereby, they asserted, making the separate depository in Minnesota-containing a hard copy of everything on the websites-unnecessary. ${ }^{13}$ Electronic media and oversized

Table 2 The Public Health Intervenors in the USA's racketeering case against the tobacco industry

The Intervenors are the following six public health groups that obtained party status through a legal procedure allowing them to join the case after the USA dramatically lowered the level of funding it was seeking for certain remedies, such as smoker cessation and counter-marketing

American Cancer Society

Americans for Nonsmokers'

Rights

American Lung Association

National African American Tobacco Prevention Network

American Heart Association
Tobacco-Free Kids Action Fund documents, such as electronic data and larger than $8.5^{\prime \prime} \times 11^{\prime \prime}$ standard paper size, have been historically made available to the public at the Minnesota Depository and not at the court-ordered tobacco company document websites created under the MSA. Additionally, the Defendants argued that the Depository was rarely used because it is inconveniently located (particularly as compared with the Defendants' websites, available to anyone with an internet connection) and costly to maintain-citing that the Defendants jointly pay \$US\$1000000 annually to maintain it. ${ }^{14}$ Finally, while the Defendants recognised that there were some discrepancies between documents physically housed at the Minnesota Depository and those on their websites, they argued that those would soon be resolved entirely. In short, they argued that " $\mathrm{t}]$ he Minnesota Depository ha[d] run its course." 15

The USA explained that allowing the Minnesota Depository to close would remove "a valuable resource that has directly led to important discoveries about Defendants' past frauds and deceptions" and "the only check on the accuracy and completeness of the documents that Defendants post to their document websites...leaving Defendants wholly on their own to police... whatever documents they chose to post."16

In fact, after comparing the 4(b) Index at the Minnesota Depository, which is the electronic catalogue of documents housed at the Minnesota Depository, with the indices from the Defendants' websites, LTDL staff discovered that over 100000 documents housed at the Minnesota Depository were not available on the defendants' websites. ${ }^{17}$ The USA informed the Court that documents listed on the 4(b) Index and publicly available in hard copy at Minnesota were not on Defendants' document websites. ${ }^{18}$ The USA also pointed out that if a document went missing from the Defendants' websites, it could only be obtained through the Minnesota Depository. ${ }^{19}$ Last, despite the Defendants' claims that the Minnesota Depository is rarely used, $^{20} 21$ the USA noted that from May 2008, when the Minnesota Depository would have closed under the terms of the Minnesota settlement, to March 2011, over 350 unique requests for documents or other information were received by the Minnesota Depository staff. ${ }^{22}$

Both the USA and Intervenors ${ }^{23}$ relied extensively on declarations made by long-time tobacco control researchers, lawyers and advocates who used the Minnesota Depository to find evidence detailing the tobacco industry's 'fraud, deception and subterfuge' in their publications ${ }^{24-30}$ They explained that hard copy searches of documents were critical in researching their published works for many reasons, including the value of serendipitous findings in a box of documents that would be completely unrelated to any electronic search term inputted into a database and the increased ease of contextualising documents among related people, entities and subject matters, among other findings. These individuals also highlighted the types of materials housed only within the Minnesota Depository, such as threedimensional trial exhibits, volumes of microfilm, slides, reel-to-reel tapes, audio and video recordings, and separate hard drives or databases. In addition to the unique resources and searching methodologies available at the Minnesota Depository, it is currently estimated to house over 25000 boxes of documents or approximately 55-60 million pages (up from about 26 million pages in late $1998^{31}$; Minnesota Tobacco Document Depository, personal communication, April 2014).

In response to the Plaintiffs' arguments, the Defendants withdrew their request to close the Minnesota Depository, acknowledging that, among other things, over 100000 documents discovered by LTDL staff were not on their own websites. ${ }^{32}$ 
Documents kept from public view for years at the Minnesota Depository are ordered to be released for public inspection

In December 2011, Judge Kessler stated that "there is some degree of confusion and uncertainty about the proper" handling of certain documents at the Minnesota Depository. ${ }^{33}$ The Depository has a Secured Documents Room (SDR) on the premises, containing records not available for public review. Under the Minnesota Settlement, the Defendants had the authority to review documents available to the public and move them to the SDR for various reasons, including that, in the Defendants' view, they should not have been produced to the Minnesota Depository in the first place or were otherwise privileged or confidential.

Explaining that " $[\mathrm{w}]$ hen removals are not handled properly, the public suffers because the removed documents are no longer available for public inspection," Judge Kessler directed that "no Defendant shall remove any documents from the population available to the public at the Depository until further Order of the Court."34 Subsequently, Judge Kessler directed the Defendants to correct all errors and discrepancies concerning their document and index productions, and that any future errors must be corrected within 30 days. ${ }^{35}$ She further directed that by June 2012, each Defendant needed to file a Privilege Log identifying "each document that was at one time submitted to be part of the publicly available population but which has subsequently been removed by Defendants as privileged or for any other reason," and, for each such document, "whether proper removal procedures were followed..."35

In June 2012, and in compliance with Judge Kessler's Order, each Defendant filed information and Privilege Logs explaining which documents had been moved from public access to the SDR. ${ }^{36-38}$ The information showed that more than 3000 documents had been moved.

The Parties subsequently developed a procedure to allow the USA or Intervenors to challenge whether these documents belonged in the public domain. ${ }^{39}$ As of the end of 2013, Plaintiffs had completed this process with all Defendants but Lorillard. ${ }^{40}$ Although the process is continuing, thus far, over 2300 documents have been returned to public access at the Minnesota Depository and at Defendants' tobacco document websites.

\section{Tobacco company document websites}

As previously noted, Judge Kessler decided there should be further consideration of the Defendants' document website coding obligations. After the nearly 4-year appeals process was over, she directed the Parties into mediation to seek to resolve that issue.

As a result, in December 2011 the Parties submitted two joint proposed Consent Orders, subsequently approved by the Court, ${ }^{41} 42$ modifying the Defendants' document disclosure and website coding obligations. Under the Orders, the Defendants are required, among other things, to (1) pay US\$6.9 million over 4 years to the Court, which then disburses the payments to University of California San Francisco (UCSF) to improve access to and functionality of LTDL; and (2) follow certain technical requirements for coding and posting documents to their existing tobacco document websites. In exchange for these commitments, the Consent Orders excuse the Defendants from coding the 'person mentioned', 'organisation mentioned' and 'brand mentioned' fields when posting documents on their websites.

\section{Current document coding and posting obligations on the Defendants' document websites}

Under the Consent Orders, the Defendants will continue to code many of the fields that they were required to under prior
MSA obligations, as well as some new fields and are required to follow a new timeline for document disclosure to the public (table 3). Taken together, these measures allow the public to better track documents being produced in litigation and to determine whether the Defendants are meeting their transparency obligations.

\section{Challenges to redactions on publicly available documents}

Defendants are allowed to redact (remove information by covering it with a box or highlighting making the original text unreadable) personal confidential information such as personal email addresses and phone numbers of tobacco company employees, or families and names where the document also links the named person to certain kinds of information (eg, sexual orientation, medical information). However, under the Consent Orders, the USA and Intervenors may request that certain personal confidential redactions be lifted where they are broader than the limited list of allowable redactions. To facilitate that process, LTDL provides a link where users can get assistance in inquiring whether a redaction can be lifted. ${ }^{43}$

\section{Court fund to improve public access to the documents}

The Consent Orders require the Defendants to provide \$6.9 million to the Court, which disburses the funds to UCSF to improve public access to the documents via LTDL. The funds will pay for enhancing the indexing of newly added documents, specifically by adding the names of people, organisations and brands mentioned in the documents. Additionally, they will be used to help redesign LTDL's infrastructure (search and retrieval software tools) and its interface, which is expected to be released in September 2014 (box 1).

Last, under the Consent Orders, the Defendants must consult with LTDL staff, at LTDL's request, in an effort to resolve technical issues. This is the first time that the tobacco companies are required to designate a person with sufficient authority to whom issues about document access could be brought. In the past 2 years, consultations were held on missing documents, incorrect metadata and index formatting problems and were generally resolved to the satisfaction of LTDL staff.

\section{Table 3 New Timeline for Defendants document disclosure to the public}

\begin{tabular}{ll}
$\begin{array}{l}\text { Number of days from the date a } \\
\text { document is produced to plaintiffs } \\
\text { in US-based smoking and } \\
\text { health-related litigation }\end{array}$ & \begin{tabular}{l} 
Defendant's obligation \\
\hline 14
\end{tabular} \\
\hline $\begin{array}{l}\text { Post electronic indices on their websites } \\
\text { identifying specific documents by bates } \\
\text { number, litigation action, the date on } \\
\text { which it was produced to plaintiffs, and } \\
\text { whether the document is subject to an } \\
\text { internal review for confidential } \\
\text { information such as trade secret or } \\
\text { personal confidential information }\end{array}$ \\
$\begin{array}{l}\text { Post documents on their websites and } \\
\text { deposit them at the Minnesota } \\
\text { Depository } \\
\text { Post documents subject to a } \\
\text { confidentiality review on their websites } \\
\text { and at the Minnesota Depository }\end{array}$ \\
\hline
\end{tabular}


Box 1 Enhancements on the Legacy Tobacco Documents Library (LTDL) redesigned site expected to be released in September 2014

- Enhanced search and retrieval software tools on LTDL.

- Log-in option allowing repeat users to save citations, search history and edit preferences (eg, how many results to display, sorting options, preferred citation format).

- Faceted searches giving users the option to filter results by date, document type and other parameters.

- Better suppression of duplicates and confidential documents.

- Timelines showing document dates in graphical form.

- More accurate relevancy ranking, easier query construction, including a "find similar documents" option, wildcard use in phrase searches and system offered search queries for misspellings (eg, "did you mean?").

\section{Growing tobacco document collection remains a valuable resource for monitoring the tobacco industry}

Although tobacco industry document management policieslargely designed to decrease litigation exposure by limiting the internal exchange of written information ${ }^{44}$-may result in less damaging disclosures than in decades past, corporate documents remain a valuable tool to monitor the US tobacco industry.

For example, a number of researchers have relied on documents dated within the past decade to expose the tobacco companies' internal strategies for producing and marketing their products. These investigators discovered documents about web-based focus groups disguised as forums for 20 -something consumers ${ }^{45}$-a key target group for tobacco companies, ${ }^{46} 47$ colour coding to connote so-called 'low tar' products to replace prohibited descriptors on packaging such as 'light' or 'ultra light', ${ }^{48}$ recent internal sensory research related to modified risk tobacco products ${ }^{49}$ and external research supported by tobacco companies. ${ }^{50}$ As of February 2014, there are 328000 documents produced by the RICO Defendants dated between 2004 and 2013 (198 705 of these are designated privileged or confidential and are therefore unavailable).

\section{CONCLUSION}

Although the document disclosure obligations under the Minnesota Settlement and the MSA ended in 2008 and 2010, respectively, ongoing requirements placed on the major US tobacco firms continue today. Documents will continue to be added to the public archives until 1 September 2021, a redesigned LTDL website with improved searching and indexing capabilities is expected in September 2014, and additional enhanced transparency measures are now in effect. The Minnesota Depository's continued existence allows the public to search and use materials unique to the facility, and check tobacco companies' compliance with its document disclosure obligations. Additionally, for the first time, a mechanism is in place to allow challenges to be made to certain redactions contained in publicly available documents, in order to prevent the companies from keeping parts of otherwise public documents secret. Last, because of the litigation effort to keep the Minnesota Depository open, approximately 100000 documents were posted online that were not previously available and another 2300 documents have been returned to the publicly accessible document collections at the Minnesota Depository and online. To the best of our knowledge, there has not been a systematic search of those documents.

Taken together, these transparency measures provide the public health community with an opportunity to not only continue to expose the tobacco industry's past bad acts, but to also monitor their ongoing behaviour. These internal corporate documents provide an opportunity to discover new internal evidence related to, among other things, the tobacco industry's market research and strategies to reach young adults aged 18-21 years, packaging and labelling tactics and product design strategies. Such new discoveries might support innovative tobacco control measures, such as increasing a minimum legal tobacco product sale age to 21 , which is currently being implemented in some US States. ${ }^{51}$ They could also support the Food and Drug Administration's (FDA) efforts to regulate tobacco products under the Family Smoking Prevention and Tobacco Control Act, although the tobacco companies have been largely successful in staving off FDA regulation. The efforts of researchers to effectively access and use these documents will likely become even easier-in terms of technical searching enhancements - with the millions of dollars being provided to facilitate user-friendly and comprehensive document research in LTDL.

\section{What this paper adds}

- We describe the recently enhanced document disclosure obligations placed on the major U.S. tobacco companies as a result of federal racketeering litigation.

- We highlight the recent public release of certain documents as a result of events in the federal racketeering litigation leading up to these new requirements.

- We describe certain document indexing enhancements and redesign to the Legacy Tobacco Document Library website, which expected to be released in September 2014.

Contributors MEM originated the idea for the manuscript and MEM, HMC and KK conducted research, participated in drafting, reviewing and editing the manuscript.

\section{Competing interests None.}

Provenance and peer review Not commissioned; externally peer reviewed.

Open Access This is an Open Access article distributed in accordance with the Creative Commons Attribution Non Commercial (CC BY-NC 4.0) license, which permits others to distribute, remix, adapt, build upon this work non-commercially, and license their derivative works on different terms, provided the original work is properly cited and the use is non-commercial. See: http://creativecommons.org/ licenses/by-nc/4.0/

\section{REFERENCES}

1 USCF Legal Tobacco Documents Library: Tobacco Industry Document Bibliography, Papers and Publications based on Document Research. http://www.library.ucsf.edu/ tobacco/docsbiblio (accessed 22 Apr 2014).

2 The State of Minnesota and Blue Cross Blue Shield of Minnesota v. Philip Morris et. al. Consent Judgment. Court File No. C1-94-8565. 8 May 1998. Paragraph VII(E). http://www.library.ucsf.edu/sites/all/files/ucsf_assets/mnconsent.pdf (accessed 14 Apr 2014).

3 Master Settlement Agreement. Paragraphs IV(c) and IV(d). 23 November 1998. http://www.naag.org/backpages/naag/tobacco/msa/msa-pdf/MSA\%20with\%20Sig\% 20Pages\%20and\%20Exhibits.pdf/file_view (accessed 22 Apr 2014).

4 Hurt RD, Ebbert JO, Muggli ME, et al. Open doorway to truth: legacy of the Minnesota tobacco trial. Mayo Clin Proc 2009;84:446-56.

5 US Department of Justice website. Civil Division, Litigation Against Tobacco Companies. http://www.usdoj.gov/civil/cases/tobacco2/index.htm (accessed 22 Apr 2014).

6 United States v. Philip Morris USA, Inc. Final Judgment and Remedial Order. 17 August 2006. http://www.library.ucsf.edu/sites/all/files/ucsf_assets/final_judgment_ order.pdf (accessed 23 Apr 2014). 
7 The other remedies Judge Kessler imposed were (1) an injunction against further violations; (2) a prohibition on "low-tar" or other descriptors, and (3) corrective statements Defendants must communicate to the public

8 United States v. Philip Morris USA, Inc. Document No. 5765. ORDER \#1021. 20 September 2006. http://mww.library.ucsf.edu/sites/all/files/ucsf_assets/DN5765_09-20-2006.pdf

9 United States v. Philip Morris USA, Inc. Document No. 5901. MEMORANDUM OPINION. 28 March 2011. http://www.library.ucsf.edu/sites/all/files/ucsf_assets/ DN5901 03-28-2011.pdf

10 United States Court of Appeals. United States v. Philip Morris USA, Inc. 22 May 2009. http://www.library.ucsf.edu/sites/all/files/ucsf_assets/CADC\%20opinion\%20(5 22.2009).pdf (accessed 22 Apr 2014).

11 United States v. Philip Morris USA, Inc. Document No. 5899, p. 4. UNITED STATES OPENING BRIEF ON DEFENDANTS' RULE 60(b) MOTION TO CLOSE THE MINNESOTA DEPOSITORY. 24 March 2011. http://www.library.ucsf.edu/sites/all/files/ ucsf_assets/DN5899_03-24-2011.pdf

12 United States v. Philip Morris USA, Inc. Document No. 5949. ORDER \# 26Remand. 18 August 2011. http://www.library.ucsf.edu/sites/all/files/ucsf_assets/ DN5949_08-18-2011.pdf

13 United States v. Philip Morris USA, Inc. Document No. 5897-1. CERTAIN DEFENDANTS' MEMORANDUM OF POINTS AND AUTHORITIES IN SUPPORT OF THEIR MOTION TO MODIFY ORDER \#1015 TO REMOVE THE MINNESOTA DEPOSITORY REQUIREMENTS. 24 March 2011. http://www.library.ucsf.edu/sites/all/ files/ucsf_assets/DN5897-1_03-24-2011.pdf

14 United States v. Philip Morris USA, Inc. Document No. 5897-1, p 8-11. CERTAIN DEFENDANTS' MEMORANDUM OF POINTS AND AUTHORITIES IN SUPPORT OF THEIR MOTION TO MODIFY ORDER \#1015 TO REMOVE THE MINNESOTA DEPOSITORY REQUIREMENTS. 24 March 2011. http://www.library.ucsf.edu/sites/all/ files/ucsf assets/DN5897-1_03-24-2011.pdf

15 United States v. Philip Morris USA, Inc. Document No. 5897-1, p 13. CERTAIN DEFENDANTS' MEMORANDUM OF POINTS AND AUTHORITIES IN SUPPORT OF THEIR MOTION TO MODIFY ORDER \#1015 TO REMOVE THE MINNESOTA DEPOSITORY REQUIREMENTS. 24 March 2011. http://www.library.ucsf.edu/sites/all/ files/ucsf_assets/DN5897-1_03-24-2011.pdf

16 United States v. Philip Morris USA, Inc. Document No. 5899, p. 1-2. UNITED STATES' OPENING BRIEF ON DEFENDANTS' RULE 60(b) MOTION TO CLOSE THE MINNESOTA DEPOSITORY. 24 March 2011. http://www.library.ucsf.edu/sites/all/files/ ucsf assets/DN5899 03-24-2011.pdf

17 United States v. Philip Morris USA, Inc. Document No. 5899, p. 15. UNITED STATES' OPENING BRIEF ON DEFENDANTS' RULE 60(b) MOTION TO CLOSE THE MINNESOTA DEPOSITORY. 24 March 2011. http://www.library.ucsf.edu/sites/all/files/ ucsf_assets/DN5899 03-24-2011.pdf

18 United States v. Philip Morris USA, Inc. Document No. 5911, p. 1,10. UNITED STATES' REPLY BRIEF ON DEFENDANTS' RULE 60(b) MOTION TO CLOSE THE MINNESOTA DEPOSITORY. 5 April 2011. http://www.library.ucsf.edu/sites/all/files/ ucsf_assets/DN5911_04-05-2011.pdf

19 United States v. Philip Morris USA, Inc. Document 5899, p. 16. UNITED STATES OPENING BRIEF ON DEFENDANTS' RULE 60(b) MOTION TO CLOSE THE MINNESOTA DEPOSITORY. 24 March 2011. http://www.library.ucsf.edu/sites/all/files/ ucsf_assets/DN5899_03-24-2011.pdf

20 United States v. Philip Morris USA, Inc. Document No. 5897-1, p.3. CERTAIN DEFENDANTS' MEMORANDUM OF POINTS AND AUTHORITIES IN SUPPORT OF THEIR MOTION TO MODIFY ORDER \#1015 TO REMOVE THE MINNESOTA DEPOSITORY REQUIREMENTS. 24 March 2011. http://www.library.ucsf.edu/sites/all/ files/ucsf_assets/DN5897-1_03-24-2011.pdf

21 United States v. Philip Morris USA, Inc. Document No. 5912, p.1. CERTAIN DEFENDANTS' RESPONSE TO THE UNITED STATES' AND INTERVENORS' BRIEFS REGARDING THE MINNESOTA DEPOSITORY REQUIREMENTS. 5 April 2011. http://www.library.ucsf.edu/sites/all/files/ucsf_assets/DN5912_ 04-05-2011.pdf

22 United States v. Philip Morris USA, Inc. Document No. 5899, p. 20. UNITED STATES' OPENING BRIEF ON DEFENDANTS' RULE 60(b) MOTION TO CLOSE THE MINNESOTA DEPOSITORY. 24 March 2011. http://www.library.ucsf.edu/sites/all/files/ ucsf_assets/DN5899_03-24-2011.pdf

23 United States v. Philip Morris USA, Inc. Document No. 5898. PUBLIC HEALTH INTERVENORS' OPENING BRIEF ON DEFENDANTS' RULE 60(b) MOTION REGARDING THE MINNESOTA DEPOSITORY. 24 March 2011. http://www.library. ucsf.edu/sites/all/files/ucsf_assets/DN5898_03-24-2011.pdf

24 United States v. Philip Morris USA, Inc. Document No. 5899, p. 9. UNITED STATES' OPENING BRIEF ON DEFENDANTS' RULE 60(b) MOTION TO CLOSE THE MINNESOTA DEPOSITORY. 24 March 2011. http://www.library.ucsf.edu/sites/all/files/ ucsf_assets/DN5899_03-24-2011.pdf

25 United States v. Philip Morris USA, Inc. Document No. 5899-8. DECLARATION OF NORBERT HIRSCHHORN, MD. 24 March 2011. http://www.library.ucsf.edu/sites/all/ files/ucsf_assets/DN5899-8_HirschhornDeclaration.pdf

26 United States v. Philip Morris USA, Inc. Document No. 5899-5. DECLARATION OF ERIC MICHAEL LEGRESLEY, M.SC., L.L.M. 24 March 2011. http://www.library.ucsf. edu/sites/all/files/ucsf_assets/DN5899-5_LeGresleyDeclaration.pdf
27 United States v. Philip Morris USA, Inc. Document No. 5899-9. DECLARATION OF MONIQUE ELIZABETH MUGGLI, J.D., M.P.H. 24 March 2011. http://www.library. ucsf.edu/sites/all/files/ucsf_assets/DN5899-9_MuggliDeclaration.pdf

28 United States v. Philip Morris USA, Inc. Document No. 5899-6. DECLARATION OF KIM KLAUSNER, M.A. 24 March 2011. http://www.library.ucsf.edu/sites/all/files/ ucsf_assets/DN5899-6_KlausnerDeclaration.pdf

29 United States v. Philip Morris USA, Inc. Document No. 5899-4. DECLARATION OF STELLA AGUINAGA BIALOUS, DR.P.H., R.N. 24 March 2011. http://www.library. ucsf.edu/sites/all/files/ucsf_assets/DN5899-4_BialousDeclaration.pdf

30 United States v. Philip Morris USA, Inc. Document No. 5899-7. DECLARATION OF RICHARD DALE HURT, M.D. 24 March 2011. http://www.library.ucsf.edu/sites/all/ files/ucsf_assets/DN5899-7_HurtDeclaration.pdf

31 Ravnitzky M, Weigum J. Filtered or unfiltered information: choices in how to make the Minnesota Tobacco Document Depository records more accessible to the public. William Mitchell Law Rev 1999;25:715-39.

32 United States v. Philip Morris USA, Inc. Document No. 5923, p.1. CERTAIN DEFENDANTS' NOTICE OF WITHDRAWAL REGARDING THEIR MOTION TO MODIFY ORDER \#1015 TO REMOVE THE MINNESOTA DEPOSITORY REQUIREMENTS. 14 April 2011. http://www.library.ucsf.edu/sites/all/files/ucsf_assets/DN5923_04-18-2011.pdf

33 United States v. Philip Morris USA, Inc. Document No. 5962. ORDER \#29-Remand. 29 December 2011. http://www.library.ucsf.edu/sites/all/files/ucsf_assets/DN5962_ 12-29-2011.pdf

34 United States v. Philip Morris USA, Inc. Document No. 5962, p. 2. ORDER \#29-Remand. 29 December 2011. http://www.library.ucsf.edu/sites/all/files/ucsf_ assets/DN5962_12-29-2011.pdf

35 United States v. Philip Morris USA, Inc. Document No. 5970. ORDER \#30-Remand. 4 April 2012. http://www.library.ucsf.edu/sites/all/files/ucsf_assets/DN5970_04-04-2012.pdf

36 United States v. Philip Morris USA, Inc. Document No. 5974. DEFENDANTS ALTRIA GROUP, INC. AND PHILIP MORRIS USA INC.'S NOTICE OF FILING. 11 June 2012. http://www.library.ucsf.edu/sites/all/files/ucsf_assets/DN5974_06-11-2012.pdf

37 United States v. Philip Morris USA, Inc. Document No. 5975. LORILLARD TOBACCO COMPANY'S SUBMISSION IN RESPONSE TO ORDER \#30 REMAND. 11 June 2012. http://www.library.ucsf.edu/sites/all/files/ucsf_assets/DN5975_06-11-2012.pdf

38 United States v. Philip Morris USA, Inc. Document No. 5976. DEFENDANT R.J. REYNOLDS TOBACCO COMPANY'S PRIVILEGE INDEXES FILED IN COMPLIANCE WITH ORDER \#30-REMAND. 11 June 2012. http://www.library.ucsf.edu/sites/all/ files/ucsf_assets/DN5976 06-11-2012.pdf

39 United States v. Philip Morris USA, Inc. Document No. 6010. ORDER \#39 REMAND CONSENT ORDER CONCERNING PROCEDURES FOR REVIEWING MINNESOTA PRIVILEGE CLAIMS. 23 April 2013. http://www.library.ucsf.edu/sites/all/files/ucsf_ assets/DN6010_04-23-2013.pdf

40 United States v. Philip Morris USA, Inc. Document No. 6022. JOINT STATUS REPORT. 10 January 2014. http://www.library.ucsf.edu/sites/all/files/ucsf_assets/ DN6022 01-10-2014.pdf

41 CONSENT ORDER BETWEEN THE UNITED STATES, THE PUBLIC HEALTH INTERVENORS, PHILIP MORRIS USA INC., ALTRIA GROUP, INC., AND R.J. REYNOLDS TOBACCO COMPANY CONCERNING DOCUMENT DISCLOSURE OBLIGATIONS UNDER ORDER \#1015. http://www.library.ucsf.edu/sites/all/files/ucsf_ assets/consentorder_USPM_20111215.pdf (accessed 22 Apr 2014).

42 CONSENT ORDER BETWEEN THE UNITED STATES, THE PUBLIC HEALTH INTERVENORS, AND LORILLARD TOBACCO COMPANY CONCERNING DOCUMENT DISCLOSURE OBLIGATIONS UNDER ORDER \#1015. http://www.library.ucsf.edu/sites/ all/files/ucsf_assets/Consent\%200rder\%20Lorillard.pdf (accessed 22 Apr 2014).

43 UCSF Legacy Tobacco Documents Library. Personal Confidential Redactions. http:// legacy.library.ucsf.edu/help/docdesignation.jsp\#redact (accessed 22 Apr 2014).

44 LeGresley EM, Muggli ME, Hurt RD. Playing hide-and-seek with the tobacco industry. Nicotine Tob Res 2005;7:27-40.

45 Savelli M, O'Connor SC, Di Sante E, et al. Packaging digital culture to young smokers. Tob Control 2015;24:303-5.

46 Ling PM, Glantz SA. Why and how the tobacco industry sells cigarettes to young adults: evidence from industry documents. Am J Public Health 2002;92: 908-16.

47 Sepe ES, Ling PM, Glantz SA. Smooth moves: bar and nightclub tobacco promotions that target young adults. Am J Public Health 2002;92:414-19.

48 Connolly GN, Aplert HR. Has the tobacco industry evaded the FDA's ban on 'Light' cigarette descriptors? Tob Control 2014;23:140-5. http://tobaccocontrol.bmj.com/ content/early/2013/03/01/tobaccocontrol-2012-050746.full (accessed 22 Apr 2014).

49 Rees VW, Kreslake JM, Wayne GF, et al. Role of cigarette sensory cues in modifying puffing topography. Alcohol Depend 2012;124:1-10. http://www.ncbi.nlm.nih.gov/ pmc/articles/PMC3371306/ (accessed 22 Apr 2014).

50 Kyriss T, Schneider NK. The development of scientific consultants: how the tobacco industry creates controversy on the carcinogenicity of tobacco-specific nitrosamines. Tob Control 2013;22:3 e3. http://tobaccocontrol.bmj.com/content/early/2012/09/01/ tobaccocontrol-2012-050696. full\#abstract-1 (accessed 22 Apr 2014).

51 Campaign for Tobacco-Free Kids. Increasing the minimum sale age for tobacco products to 21. http://www.tobaccofreekids.org/research/factsheets/pdf/0376.pdf (accessed 5 Apr 2014). 